\title{
Performance of Tuberose (Polianthes tuberosa L.) var. Prajwal as Influenced by Paclobutrazol as Foliar Spray on Quality parameters
}

\author{
Vinod Kumar Nellipalli* and Arun Kumar Pal
}

Department of Floriculture and Landscape Architecture, Bidhan Chandra Krishi

Vishwavidyalaya, Mohanpur, Nadia, W.B. - 741252, India

*Corresponding author

\section{Keywords}

Tuberose, Paclobutrazol, Spraying time, Self-life and Days after planting

Article Info

Accepted:

20 September 2018 Available Online: 10 October 2018

\section{A B S T R A C T}

A field experiment was carried out in Horticulture Research Farm, Bidhan Chandra Krishi Vishwavidyalaya, Mohanpur, to study the effect of paclobutrazol as foliar spray at different dates, on growth, flowering and bulb yield of tuberose (Polianthes tuberosa L.) var. Prajwal. The experiment was carried out during the year 2016-2018 (March - March) to find out the suitable dose of paclobutrazol and amicable time of its spraying, to get maximum flower production. The experiment was laid out in augmented factorial randomized block design with three replications. The first factor contains three different doses of Paclobutrazol application $\mathrm{P}_{1}(100 \mathrm{ppm}), \mathrm{P}_{2}(200 \mathrm{ppm}), \mathrm{P}_{3}(300 \mathrm{ppm})$ as foliar spray and the second factor is with three different times of Paclobutrazol application i.e., $\mathrm{S}_{1}$ (45 DAP), $\mathrm{S}_{2}$ (65 DAP), $\mathrm{S}_{3}$ (85 DAP). A control plot is made without any application of paclobutrazol to observe the difference in the treatment effect. Combining the two year data, the pooled data reveals that, the self-life of spike and the weight of spike was observed maximum with the application of $200 \mathrm{ppm}$ paclobutrazol at $\mathrm{S}_{2}$ (65 DAP) respectively. While the vase life of spike and floret diameter was observed maximum with the application of $300 \mathrm{ppm}$ paclobutrazol at $\mathrm{S}_{2}(65 \mathrm{DAP})$. It can be concluded that, the quality flowers of tuberose var. Prajwal could be observed with the application of paclobutrazol @ 200 ppm at 65 days after transplanting (DAP).

\section{Introduction}

Tuberose (Polianthes tuberosa L.) is an important commercial flower crop and is extensively cultivated in many sub-tropical and tropical parts of the world including India.

It is a native of Mexico, belongs to the family Amaryllidaceae. Tuberose is a bulbous perennial plant with tuberous roots producing long spikes, which bear waxy white and fragrant flowers profusely throughout the year.
In India, commercial tuberose cultivation is confined to one species Polianthes tuberosa, which is basically a white flowered type. There are four tuberose cultivars popularly grown in India viz., single, double, semi double and variegated. The cultivar single occupies the foremost position than the other. Apart from domestic consumption, tuberose cut spikes has got a very good export potential to other countries. Tuberose floral concrete and essential oil are fetching higher price than any other floral concretes and essential oils. 
Plant growth regulators are known to regulate and control various phases of growth and development, including flowering at optimum concentrations. It is generally accepted that exogenously applied growth substances act through the alteration in the levels of naturally occurring hormones, thus modifying the growth and development of the plant. Hence, the present study was undertaken to study the effects of paclobutrazol as foliar spray on flowering of tuberose variety Prajwal.

\section{Materials and Methods}

The experiment was carried out during the year 2016-2018, at the Horticulture Research Farm, Mondouri, at the Bidhan Chandra Krishi Vishwavidyalaya, Mohanpur. The experiment was laid out in augmented factorial randomized block design with three replications. First factor comprises of three different doses of paclobutrazol application $\mathrm{P}_{1}$ (100 ppm), $\mathrm{P}_{2}$ (200 ppm), $\mathrm{P}_{3}(300 \mathrm{ppm})$ as foliar spray and the second factor is with three different times of Paclobutrazol application i.e., $S_{1}$ (45 DAP), $S_{2}$ (65 DAP), $S_{3}$ (85 DAP). Along with these treatments one control plot is made. During the field preparation, well rotten farm yard manure @ $1.5 \mathrm{~kg} / \mathrm{m}^{2}$ was applied as basal dose 15 days before planting and mixed properly with soil. N: P: K @ 150: 200: 200 $\mathrm{kg} / \mathrm{ha}$ was applied, in which, half $\mathrm{N}$, full $\mathrm{P}$ and $\mathrm{K}$ applied as basal, remaining $\mathrm{N}$ applied as split doses, 30 and 45 days after planting. The size of the plot was $1.5 \mathrm{~m} \times 1.0 \mathrm{~m}$ with a spacing of $30 \mathrm{~cm} \times 30 \mathrm{~cm}$.

Bulbs of tuberose cv. Prajwal were provided by Horticulture Research Farm, Mandouri, Bidhan Chandra Krishi Vishwavidyalaya. Before planting the bulbs were stored in well ventilated semi shady place for two months. Older leaves emerging from the neck of the bulbs were trimmed off. Before planting, the bulbs were treated with fungicide copper oxychloride $(0.1 \%)$ and the individual bulbs weighing $15-30 \mathrm{~g}$ with $1.5-2.5 \mathrm{~cm}$ in diameter were selected for planting. Five plants were selected randomly from each plot for recording data on various quality attributes. The data on flowering were recorded during the course of investigation and subjected to statistical analysis as per Panse and Sukhatme (1967). The appropriate standard error of mean S.E. (m) and the critical difference (C.D.) were calculated at $5 \%$ level of probability.

\section{Results and Discussion}

The quality parameters discussed in this research article are, Self-life, vase life, weight of spike and floret diameter of tuberose var. Prajwal.

\section{Paclobutrazol}

\section{Self-life}

Data presented in the Table 1 reveals that the effect due to different levels of paclobutrazol on the self-life of spike was found significant. In the main crop, significantly maximum selflife of spike (23.68 days) was recorded in $\mathrm{P}_{2}$ (Paclobutrazol $200 \mathrm{ppm}$ ), which was found at par with $\mathrm{P}_{3}$ (23.67 days). The minimum selflife of spike (21.61 days) was recorded in $\mathrm{P}_{1}$ (Paclobutrazol $100 \mathrm{ppm}$ ). In the ratoon crop, significantly maximum self-life of spike (25.31 days) was recorded in $\mathrm{P}_{2}$ (Paclobutrazol $200 \mathrm{ppm}$ ), which was found at par with $\mathrm{P}_{3}$ (24.08 days). However, the minimum self-life of spike (21.17 days) was recorded in $\mathrm{P}_{1}$ (Paclobutrazol $100 \mathrm{ppm}$ ).

In the pooled data mean maximum self-life of spike (24.50 days) was recorded in $\mathrm{P}_{2}$ (Paclobutrazol $200 \mathrm{ppm}$ ), which was found at par with $\mathrm{P}_{3}$ (23.87 days). However, significantly, minimum self-life of spike (21.39 days) was recorded in $\mathrm{P}_{1}$ (Paclobutrazol 100 ppm). 
Increase in longevity of flower might be due to maintenance of chlorophyll, protein and RNA content of leaves at a higher level for a longer duration which suppresses the senescence (Kar et al., 1989). Similar type of results was obtained by Khan and Pal (2009) in Tuberose and Suradinatha and Hamdani (2015) in Rose.

\section{Vase life}

The effect due to different levels of paclobutrazol on the vase life of spike was found significant. In the main crop, maximum vase life of spike (10.83 days) was recorded in $\mathrm{P}_{3}$ (Paclobutrazol $300 \mathrm{ppm}$ ), which was found at par with $\mathrm{P}_{2}$ (10.37 days). Significantly, minimum vase life of spike (9.72 days) was recorded in $\mathrm{P}_{1}$ (Paclobutrazol $100 \mathrm{ppm}$ ). In the ratoon crop, the maximum vase life of spike (10.81 days) was recorded in $\mathrm{P}_{3}$ (Paclobutrazol $300 \mathrm{ppm}$ ), which was found at par with $\mathrm{P}_{2}$ (10.45 days). However, the minimum vase life of spike (10.05 days) was recorded in $\mathrm{P}_{1}$ (Paclobutrazol 100 ppm).

In the pooled data, irrespective of paclobutrazol levels mean maximum vase life of spike (10.82 days) was recorded in P3 (Paclobutrazol $300 \mathrm{ppm}$ ), which was found at par with $\mathrm{P}_{2}$ (10.41 days). However, the minimum vase life of spike (9.34 days) was recorded in $\mathrm{P}_{1}$ (Paclobutrazol $100 \mathrm{ppm}$ ). Application of $300 \mathrm{ppm}$ paclobutrazol increased vase life which might be due to reduced physiological weight loss and more water uptake by flowers. The longest shelf life of flowers might be due to reduced metabolism restricted respiration due to inhibitory action of growth retardant. Similar type of results was obtained by Sebastian et al., (2002) in carnation.

\section{Weight of spike}

The data on weight of spike revealed that there was a significant effect of paclobutrazol on weight of spike. In the year 2016-17, the application of $\mathrm{P}_{2}$ (Paclobutrazol $200 \mathrm{ppm}$ ) had given the highest weight of spike (97.76 g) which was at par with $\mathrm{P}_{3}(95.15 \mathrm{~g})$, while the lowest weight of spike (93.55 g) was observed in $\mathrm{P}_{1}$ (Paclobutrazol 100 ppm).

In the year 2017-18, maximum weight of spike $\left(\begin{array}{ll}107.83 & \mathrm{~g}\end{array}\right)$ was obtained in $\mathrm{P}_{2}$ (Paclobutrazol $200 \mathrm{ppm}$ ), which was at par with $\mathrm{P}_{3}(101.17 \mathrm{~g})$, while the lowest weight of spike $(100.52 \mathrm{~g})$ was observed in $\mathrm{P}_{1}$ (Paclobutrazol 100 ppm).

The data in the Table 1 shows that the pooled data for weight of spike was significant with the application of different levels of paclobutrazol. The maximum weight of spike (102.8 g) was observed in $\mathrm{P}_{2}$ (Paclobutrazol $200 \mathrm{ppm})$ which was followed by $\mathrm{P}_{3}(98.16 \mathrm{~g})$, while the minimum spike weight $(97.04 \mathrm{~g})$ was observed in $\mathrm{P}_{1}$ (Paclobutrazol $100 \mathrm{ppm}$ ). The above results are in conformity with Dani et al., (2010) in African marigold.

\section{Flower diameter}

The data on floret diameter $(\mathrm{cm})$ revealed that there was a significant effect of paclobutrazol and spraying time on floret diameter. In the year 2016-17, the treatment $\mathrm{P}_{3}$ (Paclobutrazol $300 \mathrm{ppm}$ ) had given the highest floret diameter $(4.78 \mathrm{~cm})$ which was at par with $\mathrm{P}_{2}$ $(4.74 \mathrm{~cm})$, while the lowest floret diameter $\left(4.57 \mathrm{~cm}\right.$ ) was observed in $\mathrm{P}_{1}$ (Paclobutrazol $100 \mathrm{ppm})$. In the year 2017-18, maximum floret diameter $(4.75 \mathrm{~cm})$ was in $\mathrm{P}_{3}$ (Paclobutrazol $300 \mathrm{ppm}$ ), and it was followed by $\mathrm{P}_{2}(4.66 \mathrm{~cm})$, while the lowest floret diameter $\left(\begin{array}{ll}4.39 & \mathrm{~cm}\end{array}\right)$ was observed $\mathrm{P}_{1}$ (Paclobutrazol 100 ppm).

The data in the Table 1 shows that with the application of different levels of paclobutrazol, the pooled data for floret diameter was found significant. 
Table.1 Effect of Paclobutrazol at different spraying times on Quality parameters of Tuberose (Polianthes tuberosa L.) var. Prajwal

\begin{tabular}{|c|c|c|c|c|c|c|c|c|c|c|c|c|}
\hline \multirow[t]{4}{*}{ Treatments } & \multicolumn{3}{|c|}{ Self-life of spike (days) } & \multicolumn{3}{|c|}{ Vase life of spike (days) } & \multicolumn{3}{|c|}{ Weight of spike (g) } & \multicolumn{3}{|c|}{ Floret diameter $(\mathrm{cm})$} \\
\hline & \multirow{3}{*}{$\begin{array}{c}\text { Main } \\
\text { crop } \\
\text { 2016-17 }\end{array}$} & \multirow{3}{*}{\begin{tabular}{|c|} 
Ratoon \\
Crop \\
$2017-$ \\
18 \\
\end{tabular}} & \multirow[t]{3}{*}{ Pooled } & \multirow{3}{*}{$\begin{array}{c}\text { Main } \\
\text { crop } \\
\text { 2016-17 }\end{array}$} & \multirow{3}{*}{$\begin{array}{c}\text { Ratoon } \\
\text { Crop } \\
\text { 2017-18 }\end{array}$} & \multirow[t]{3}{*}{ Pooled } & \multirow{3}{*}{$\begin{array}{c}\text { Main } \\
\text { crop } \\
\text { 2016-17 }\end{array}$} & \multirow{3}{*}{$\begin{array}{c}\text { Ratoon } \\
\text { Crop } \\
\text { 2017-18 }\end{array}$} & \multirow[t]{3}{*}{ Pooled } & \multirow{3}{*}{$\begin{array}{c}\text { Main } \\
\text { crop } \\
\text { 2016-17 }\end{array}$} & Ratoon & \multirow[t]{3}{*}{ Pooled } \\
\hline & & & & & & & & & & & Crop & \\
\hline & & & & & & & & & & & 2017-18 & \\
\hline \multicolumn{13}{|l|}{$\begin{array}{l}\text { Paclobutrazol } \\
\text { (P) }\end{array}$} \\
\hline$P_{1}(100$ ppm $)$ & 21.61 & 21.17 & 21.39 & 9.72 & 10.05 & 9.34 & 93.55 & 100.52 & 97.04 & 4.57 & 4.39 & 4.48 \\
\hline$P_{2}(200$ ppm) & 23.68 & 25.31 & 24.50 & 10.37 & 10.45 & 10.41 & 97.76 & 107.83 & 102.8 & 4.74 & 4.66 & 4.70 \\
\hline $\mathbf{P}_{3}(300 \mathrm{ppm})$ & 23.52 & 24.08 & 23.87 & 10.83 & 10.81 & 10.82 & 95.15 & 101.17 & 98.16 & 4.78 & 4.75 & 4.76 \\
\hline $\operatorname{S.Em}( \pm)$ & 0.252 & 0.262 & 0.180 & 0.114 & 0.133 & 0.084 & 1.071 & 1.142 & 0.783 & 0.052 & 0.051 & 0.036 \\
\hline C.D at $5 \%$ & 0.748 & 0.777 & 0.515 & 0.337 & 0.396 & 0.242 & 3.183 & 3.393 & 2.246 & 0.155 & 0.152 & 0.105 \\
\hline \multicolumn{13}{|l|}{$\begin{array}{l}\text { Spraying time } \\
\text { (S) }\end{array}$} \\
\hline $\mathrm{S}_{1}(45 \mathrm{DAP})$ & 23.04 & 23.65 & 23.34 & 10.41 & 10.36 & 10.39 & 95.26 & 102.75 & 99.00 & 4.70 & 4.56 & 4.63 \\
\hline $\mathrm{S}_{2}(65 \mathrm{DAP})$ & 24.58 & 24.71 & 24.68 & 10.63 & 10.91 & 10.77 & 99.81 & 106.79 & 103.30 & 4.75 & 4.74 & 4.74 \\
\hline $\mathrm{S}_{3}(85 \mathrm{DAP})$ & 21.33 & 22.19 & 21.76 & 9.88 & 10.05 & 9.97 & 91.38 & 99.98 & 95.63 & 4.66 & 4.50 & 4.58 \\
\hline $\operatorname{S.Em}( \pm)$ & 0.252 & 0.262 & 0.180 & 0.114 & 0.133 & 0.084 & 1.071 & 1.142 & 0.783 & 0.052 & 0.051 & 0.036 \\
\hline C.D at $5 \%$ & 0.748 & 0.777 & 0.515 & 0.337 & 0.396 & 0.242 & 3.183 & 3.393 & 2.246 & N. S & 0.152 & 0.105 \\
\hline Control & 19.24 & 18.78 & 19.01 & 8.67 & 9.01 & 8.84 & 83.41 & 84.23 & 83.82 & 4.06 & 3.96 & 4.01 \\
\hline
\end{tabular}


Table.2 Interaction effect of Paclobutrazol and Spraying time on self-life and weight of spike of tuberose cv. Prajwal

\begin{tabular}{|c|c|c|c|c|c|c|}
\hline \multirow[t]{2}{*}{ Treatments } & \multicolumn{3}{|c|}{ Self-life of spike (days) } & \multicolumn{3}{|c|}{ Weight of spike (g) } \\
\hline & $\begin{array}{c}\text { Main } \\
\text { crop } \\
\text { 2016-17 }\end{array}$ & $\begin{array}{c}\text { Ratoon } \\
\text { Crop } \\
\text { 2017-18 }\end{array}$ & Pooled & $\begin{array}{c}\text { Main } \\
\text { crop } \\
\text { 2016-17 }\end{array}$ & $\begin{array}{c}\text { Ratoon } \\
\text { Crop } \\
\text { 2017-18 }\end{array}$ & Pooled \\
\hline \multicolumn{7}{|l|}{$\begin{array}{l}\text { Paclobutrazol } x \\
\text { Spraying time }\end{array}$} \\
\hline $\mathbf{P}_{1} \mathbf{S}_{1}$ & 21.22 & 20.75 & 20.98 & 93.53 & 99.34 & 96.43 \\
\hline $\mathbf{P}_{1} \mathbf{S}_{2}$ & 23.38 & 22.36 & 22.87 & 96.89 & 105.32 & 101.10 \\
\hline $\mathbf{P}_{1} \mathbf{S}_{3}$ & 20.23 & 20.41 & 20.32 & 90.24 & 96.92 & 93.58 \\
\hline $\mathbf{P}_{2} \mathbf{S}_{1}$ & 24.27 & 25.64 & 24.96 & 98.54 & 107.25 & 102.89 \\
\hline $\mathbf{P}_{2} \mathbf{S}_{2}$ & 25.12 & 26.47 & 25.80 & 100.2 & 111.42 & 105.81 \\
\hline $\mathbf{P}_{2} \mathbf{S}_{3}$ & 21.65 & 23.82 & 22.74 & 94.54 & 104.82 & 99.68 \\
\hline $\mathbf{P}_{3} \mathbf{S}_{1}$ & 23.63 & 24.56 & 24.10 & 93.73 & 101.66 & 97.69 \\
\hline $\mathbf{P}_{3} \mathbf{S}_{2}$ & 25.25 & 25.31 & 25.28 & 102.36 & 103.64 & 103.00 \\
\hline $\mathbf{P}_{\mathbf{3}} \mathbf{S}_{3}$ & 22.12 & 22.36 & 22.24 & 89.36 & 98.21 & 93.78 \\
\hline $\operatorname{S.Em}( \pm)$ & 0.436 & 0.453 & 0.311 & 1.856 & 1.978 & 1.356 \\
\hline C.D at $5 \%$ & N. S & 1.364 & 0.936 & 5.605 & 5.912 & 4.081 \\
\hline
\end{tabular}

The maximum floret diameter $(4.76 \mathrm{~cm})$ was in $\mathrm{P}_{3}$ (paclobutrazol $300 \mathrm{ppm}$ ), and the lowest floret diameter $(4.48 \mathrm{~cm})$ was observed $\mathrm{P}_{1}$ (Paclobutrazol 100 ppm).

The flower diameter increased with the increasing doses of paclobutrazol this is because of the fact that better flower diameter can be obtained with the better allocation of assimilates to the sink from the source. The above results are in conformity with Dani et al., (2010) in African marigold.

\section{Spraying time}

\section{Self-life}

The effect of different spraying times of paclobutrazol on the self-life of spike was found significant. In the main crop, the maximum self-life of spike (24.58 days) was found in $S_{2}$ (Spraying 65 DAP) and it was at par with $\mathrm{S}_{1}$ (23.04 days) and the minimum self-life of spike (21.33 days) was observed in $\mathrm{S}_{3}$ (Spraying 85 DAP). While in the ratoon crop i.e., (2017-18), the maximum self-life of spike (24.71 days) was found in $S_{2}$ (Spraying 45 DAP) and it was followed by $S_{1}(23.65$ days) and the minimum self-life of spike (22.19 days) was observed in $\mathrm{S}_{3}$ (Spraying 85 DAP). According to the pooled data shown in the Table 1 significantly maximum self-life of spike (24.68 days) was found in $\mathrm{S}_{2}$ (Spraying $65 \mathrm{DAP})$ and it was followed by $\mathrm{S}_{1}(23.34$ days) and the minimum self-life of spike (21.76 days) was observed in $\mathrm{S}_{3}$ (Spraying 85 DAP). The self-life of the spike and the vase life of the spike increase with the application of the paclobutrazol at 65 days after planting this might be because of the reason that, application of the paclobutrazol at the correct stage of the plant might enhance the yield and the longevity of the spike. These results are in conformity with Joshi and Reddy (2006) in China aster and Yayat and Hamdani (2015) in Rose.

\section{Vase life}

Effect of different spraying times of paclobutrazol on vase life of spike was found significant. In the main crop, the maximum 
vase life of spike (10.63 days) was found in $\mathrm{S}_{2}$ (Spraying 65 DAP) and it was at par with $\mathrm{S}_{1}$ (10.41 days) and the minimum vase life of spike (9.88 days) was observed in $\mathrm{S}_{3}$ (Spraying 85 DAP). While in the ratoon crop i.e., (2017-18), the maximum vase life of spike (10.91 days) was found in $\mathrm{S}_{2}$ (Spraying 65 DAP) and it was followed by $S_{1}(10.36$ days) and the minimum vase life of spike (10.05 days) was observed in $\mathrm{S}_{3}$ (Spraying 85 DAP)

According to the pooled data shown in the Table 1 the maximum vase life of spike (10.77 days) was found in $S_{2}$ (Spraying 65 DAP) and it was followed by $S_{1}$ (10.39 days) and the minimum vase life of spike (9.97 days) was observed in $\mathrm{S}_{3}$ (Spraying 85 DAP).These results are in conformity with Joshi and Reddy (2006) in China aster and Yayat and Hamdani, (2015) in Rose.

\section{Weight of spike}

Effect of different spraying times of paclobutrazol on weight of spike was found significant. In the main crop, the maximum weight of spike $(99.81 \mathrm{~g})$ was found in $\mathrm{S}_{2}$ (Spraying 65 DAP) and it was at par with $\mathrm{S}_{1}$ (95.26 g) and the minimum weight of spike (91.38 g) was observed in $\mathrm{S}_{3}$ (Spraying 85 DAP). While in the ratoon crop i.e., (2017$18)$, the maximum weight of spike (106.79 g) was found in $S_{2}$ (Spraying 65 DAP) and it was followed by $S_{1}(102.75 \mathrm{~g})$ and the minimum weight of spike $(99.98 \mathrm{~g})$ was observed in $\mathrm{S}_{3}$ (Spraying 85 DAP).

According to the pooled data shown in the Table 1 the maximum weight of spike (103.30 g) was found in $\mathrm{S}_{2}$ (Spraying $65 \mathrm{DAP}$ ) and it was followed by $\mathrm{S}_{1}(99.00 \mathrm{~g})$ and the minimum weight of spike $(95.63 \mathrm{~g})$ was observed in $\mathrm{S}_{3}$ (Spraying 85 DAP). Similar results were obtained with Nishith et al., (2015) in China aster.

\section{Floret diameter}

The effect of different spraying times of paclobutrazol on floret diameter of the plant was found significant. In the main crop, the data shows that the effect of spraying time on flower diameter was non-significant. In the ratoon crop different spraying times of paclobutrazol had given significant result, in which, $\mathrm{S}_{2}$ (Spraying 65 DAP) had given the highest floret diameter $(4.74 \mathrm{~cm})$, it was followed by $S_{1}(4.56 \mathrm{~cm})$, the spraying time $S_{3}$ (Spraying 85 DAP) had given lowest floret diameter $(4.50 \mathrm{~cm})$

The data in the Table 1 shows that in the pooled data, the maximum floret diameter $(4.74 \mathrm{~cm})$ was observed in $\mathrm{S}_{2}$ (Spraying 65 DAP) and the minimum floret diameter (4.58 $\mathrm{cm}$ ) was observed in $\mathrm{S}_{3}$ (Spraying 85 DAP). Similar results were obtained by Khan and Pal (2009) in Tuberose.

\section{Interaction effect of paclobutrazol doses and spraying time}

The interaction effect of paclobutrazol and different spraying time was found significant in the parameters like self-life and weight of spike but it was found non-significant in the vase life and flower diameter parameters.

The data in the Table 2 shows that the interaction effects of different levels of paclobutrazol and spraying time on self-life of spike was significant. In the pooled data, the treatment combination $\mathrm{P}_{2} \mathrm{~S}_{2}(200 \mathrm{ppm}$ PBZ and 65 DAP) had given the maximum self-life of spike (25.80 days), and the lowest self-life of spike (19.01 days) was observed in the control treatment.

Interaction effects of different levels of paclobutrazol and spraying time on weight of spike was significant for all the years and pooled data. In the pooled data, the treatment 
combination $\mathrm{P}_{2} \mathrm{~S}_{2}$ (200 ppm $\mathrm{PBZ}$ and 65 DAP) had given the maximum weight of spike of spike $(105.81 \mathrm{~g})$, and the lowest weight of spike of spike (83.82 g) was observed in the control treatment.

Application of $200 \mathrm{ppm}$ of paclobutrazol at 65 days after planting has given good quality flowers which might be because of the cessation of the paclobutrazol effect exactly at the flowering stage of the plant which ensures the release of gibberellins and diverting the assimilates to the spike and flowers which increase yield along with the longevity of florets and spikes. Similar results were obtained by Dani et al., (2010) in African marigold.

\section{References}

Dani, K. N., Patil, S. J., Patel, R. G. and Patel, N. A. 2010. Effect of growth retardants on flowering and yield of African marigold (Tagetes erecta L) cv. Double orange under south Gujarat conditions. The Asian J. of Hort. 5(2): 287-290.

Joshi, V. and Reddy, S. A. (2006). Effect of cycocel and alar on growth and flowering parameters in China aster (Callistephus chinensis L. Nees). $J$. Ornam. Hort., 9(1): 71-72.
Khan, A. and Pal, P. (2009). Effect of paclobutrazol and time of spraying on growth, flowering and bulb production of tuberose (Polianthes tuberosa L.) cv. Double. J. Interacademicia. 13(2): 133137.

Panse, S. K. and P. V. Sukhatme, 1967. Statistical methods for Agricultural workers, Indian Council of Agricultural Research, New Delhi, $3^{\text {rd }}$ edition: pp 341.

Sachs, R. M. and Kofranek, A. M., 1963. Comparative cytological studies in inhibition and promotion of stem growth in Chrysanthemum morifolium. American Journal of Botany. 50: 772779.

Sebastian, B., Gonzalez, A., Emilio, A. C., Jose, A. F. and Juan, A. F. 2002. Growth, development and color response of potted Dianthus caryophillus c.v Mondrian to paclobutrazol treatment. Scientia Horticulture. 94: 371-377.

Suradinatha, Y. R. and Hamdani, J. S. 2015. Effect of Paclobutrazol and 1- MCP (Methyl cyclo Propene) application on Rose (Rosa hybrida L.). Asian J. of Agri. Res. 9(2):69-76.

\section{How to cite this article:}

Vinod Kumar Nellipalli and Arun Kumar Pal. 2018. Performance of Tuberose (Polianthes tuberosa L.) var. Prajwal as Influenced by Paclobutrazol as Foliar Spray on Quality parameters. Int.J.Curr.Microbiol.App.Sci. 7(10): 2984-2990. doi: https://doi.org/10.20546/ijcmas.2018.710.346 